\title{
SHCAL13 SOUTHERN HEMISPHERE CALIBRATION, 0-50,000 YEARS CAL BP
}

Alan G Hogg ${ }^{1}$ Q Quan $\mathrm{Hua}^{2} \bullet$ Paul G Blackwell ${ }^{3} \cdot \mathrm{Mu} \mathrm{Niu}^{3} \bullet$ Caitlin E Buck ${ }^{3} \bullet$ Thomas P Guilderson ${ }^{4}$ Timothy J Heaton ${ }^{3} \cdot$ Jonathan G Palmer $^{5} \bullet$ Paula J Reimer ${ }^{6} \bullet$ Ron W Reimer ${ }^{6}$ Christian S M Turney ${ }^{5}$ Susan R H Zimmerman ${ }^{4}$

\begin{abstract}
The Southern Hemisphere SHCa104 radiocarbon calibration curve has been updated with the addition of new data sets extending measurements to $2145 \mathrm{cal}$ BP and including the ANSTO Younger Dryas Huon pine data set. Outside the range of measured data, the curve is based upon the ern Hemisphere data sets as presented in IntCal13, with an interhemispheric offset averaging $43 \pm 23 \mathrm{yr}$ modeled by an autoregressive process to represent the short-term correlations in the offset.
\end{abstract}

\section{INTRODUCTION}

Numerous studies have shown that the radiocarbon ages of tree rings formed at the same time in opposite hemispheres are different, with Southern Hemisphere ( $\mathrm{SH}$ ) samples being older by an average of about $40 \mathrm{yr}$. This age difference is known as the interhemispheric (or North-South) offset and varies periodically ( $\sim 130 \mathrm{yr}$ periodicity, McCormac et al. 2002) with amplitudes ranging from -2 to $83{ }^{14} \mathrm{C}$ yr for the time interval $200 \mathrm{BC}-\mathrm{AD} 1850$ (Hogg et al. 2011). The relatively older ages in the $\mathrm{SH}$ are considered due to a higher sea-air ${ }^{14} \mathrm{CO}_{2}$ flux from the larger expanse of SH oceans, with temporal perturbations resulting from variable Southern Ocean wind strength (Rodgers et al. 2011).

Although the ${ }^{14} \mathrm{C}$ calibration curves from the Northern Hemisphere $(\mathrm{NH})$ and $\mathrm{SH}$ are broadly similar, there are subtle differences between the structural forms of each curve. For this reason, calibration, and especially ${ }^{14} \mathrm{C}$ wiggle-matching, is best achieved using a dendrochronologically secure calibration data set derived from the appropriate hemisphere (McCormac et al. 2004). The conventions for calibrating SH terrestrial samples have evolved over time with the addition of new data. Mook (1986) recommended decreasing terrestrial $\mathrm{SH}{ }^{14} \mathrm{C}$ dates by $30 \mathrm{yr}$ before calibration with a $\mathrm{NH}$ curve. McCormac et al. (2002) published the first SH calibration curve, SHCal02, composed of data from New Zealand, Chile, and South Africa for the 2nd millennium AD, and recommended using a value of $41 \pm 14 \mathrm{yr}$ for correction of IntCal98 (Stuiver et al. 1998) data for the period outside this range. McCormac et al. (2004) used the same SHCal02 data sets, and extended the calibration curve beyond the range of the $\mathrm{SH}$ measurements to $11,000 \mathrm{cal} \mathrm{BP}$ by using a random effects model (Buck and Blackwell 2004) to account for the interhemispheric offset varying slowly over time, within the constraints of the offset observed from 50-1000 cal BP. The modeled offset varied from 55 to $58 \mathrm{yr}$, with an uncertainty increasing from $\pm 7.9 \mathrm{yr}$ at $1000 \mathrm{cal} \mathrm{BP}$ to $\pm 25 \mathrm{yr}$ at $11,000 \mathrm{cal} \mathrm{BP}$. They warned against calibrating samples older than 11,000 cal BP because of the possibility that large-scale carbon reservoir changes may have altered the interhemispheric offset before the Holocene.

\section{INTCAL12 WORKSHOP AND RADIOCARBON CONFERENCE 2012 RECOMMENDATIONS}

New SH calibration data sets were recently discussed at a meeting of the IntCal Working Group (IWG) convened in Paris in July 2012. The data discussed included the results currently included in

\footnotetext{
${ }^{1}$ Radiocarbon Laboratory, University of Waikato, PB 3105, Hamilton 3240, New Zealand. Corresponding author. Email: alan.hogg@waikato.ac.nz.

${ }^{2}$ Australian Nuclear Science and Technology Organisation, Locked Bag 2001, Kirrawee DC, NSW 2232, Australia. ${ }^{3}$ School of Mathematics \& Statistics, University of Sheffield, Hicks Building, Hounsfield Rd., Sheffield, United Kingdom. ${ }^{4}$ Center for Accelerator Mass Spectrometry, Lawrence Livermore National Laboratory, Livermore, California 94550, USA. ${ }^{5}$ Climate Change Research Centre and School of Biological, Earth and Environmental Sciences, University of New South Wales, Sydney, NSW 2052, Australia.

${ }^{6}$ Centre for Climate, the Environment \& Chronology (14CHRONO), School of Geography, Archaeology and Palaeoecology, Queen's University Belfast, Belfast BT7 1NN, United Kingdom.
} 
SHCal04 covering 0-1000 cal BP (McCormac et al. 2004); ANSTO data from Tasmanian wood from 325-175 cal BP shown graphically in Hua et al. (2004); results from CAMS Lawrence Livermore National Laboratory from Tasmanian wood from 2115-855 cal BP from Zimmerman et al. (2010); University of Waikato measurements on New Zealand wood from 2145-955 cal BP from Hogg et al. (2011); University of Waikato measurements on Tasmanian wood from 1205-1075 cal BP (Hogg et al. 2013a, this issue); and the ANSTO floating Younger Dryas (YD) Tasmanian Huon pine chronology $(12,679 \pm 11$ to $12,073 \pm 11 \mathrm{cal} \mathrm{BP})$ of Hua et al. (2009).

It was agreed that the Hua et al. (2004) data could be included with the 0-1000 cal BP data sets as long as the interlaboratory offsets were small. Similarly, the Zimmerman et al. (2010) Huon data, Hogg et al. (2011) kauri data and Hogg et al. (2013a, this issue) Huon data for the 1000-2000 cal BP interval could be used to extend the measured range of SHCal data as long as the laboratories showed good relative consistency. Given that few calibration data sets directly sample the atmospheric reservoir before the onset of the Holocene tree-ring record at 11,560 cal BP, it was also decided to include the floating YD Tasmanian Huon pine chronology of Hua et al. (2009).

Ratification was obtained at the International Radiocarbon Conference in Paris, France (2012) to recommend the use of the SH data from the data sets given here from 0-2145 cal BP, with an extension to $50,000 \mathrm{cal}$ BP using IntCal13 data, adjusted by a modeled offset.

\section{NEW SOUTHERN HEMISPHERE DATA SETS}

\section{0-1000 cal BP}

The SH data given in SHCal04 (McCormac et al. 2004) covering 0-1000 cal BP includes results from McCormac et al. (1998) and Hogg et al. (2002) on New Zealand trees covering 0-1000 cal BP; data from the University of Washington Quaternary Isotope Laboratory from Chilean and Tasmanian wood from 0-290 cal BP and 0-55 cal BP, respectively (Stuiver and Braziunas 1998; McCormac et al. 2002); and South African measurements from 51-115 cal BP from Pretoria (Vogel et al. 1993). In addition to these data, a few measurements of 17th and 18th century Little Ice Age (LIA) wood from Tasmania, previously published in graphical form in Hua et al. (2004), have been added (Table 1).

The decadal samples were obtained from a cross-dated tree-ring section (SRT-225) of Huon pine (Lagarostrobos franklinii) from western Tasmania $\left(42^{\circ} \mathrm{S}, 145^{\circ} \mathrm{E}\right)$. The samples were pretreated to $\alpha$ cellulose and analyzed by accelerator mass spectrometry (AMS) at ANSTO using the ANTARES facility (see Hua et al. 2004 for details). The ANSTO LIA Tasmanian Huon pine data set compares favorably with the combined Waikato (Wk) and Queen's University Belfast (QUB) decadal analyses on New Zealand cedar (Hogg et al. 2002), with the Huon measurements being older by $10.1 \pm 6.5 \mathrm{yr}$.

\section{0-2000 cal BP}

Three new data sets extend the range of measured SH data to 2145 cal BP: CAMS measurements from Tasmanian Huon pine; Waikato measurements on New Zealand kauri (Agathis australis); and Waikato measurements on Tasmanian Huon pine.

\section{CAMS Measurements of Tasmanian Huon Pine (2115-855 cal BP)}

Zimmerman et al. (2010) reported measurements on 127 dendrochronologically secure decadal Tasmanian Huon pine samples for the interval 2115-855 cal BP (165 BC-AD 1095). The ${ }^{14} \mathrm{C}$ analyses were made at the CAMS Lawrence Livermore AMS facility on wood pretreated by a modified de 
Table 1 ANSTO measurements on decadal Tasmanian Huon pine samples: 325-175 cal BP (AD 1625-1775) presented graphically in Hua et al. (2004).

\begin{tabular}{lllllll}
\hline Lab code & $\begin{array}{l}\text { yr BP } \\
\text { (midpoint) }\end{array}$ & $\begin{array}{l}\text { yr AD } \\
\text { (midpoint) }\end{array}$ & $\begin{array}{l}\text { Nr of } \\
\text { rings }\end{array}$ & $\begin{array}{l}{ }^{14} \mathrm{C} \text { age } \\
(\mathrm{BP})\end{array}$ & $\begin{array}{l}{ }^{14} \mathrm{C} \\
\text { error }\end{array}$ & $\begin{array}{l}\delta^{13} \mathrm{C} \\
(\%)\end{array}$ \\
\hline OZF930 & 325 & 1625 & 10 & 361 & 23 & -23.5 \\
OZF931 & 315 & 1635 & 10 & 303 & 24 & -22.6 \\
OZE978 & 305 & 1645 & 10 & 331 & 22 & -21.8 \\
OZE979 & 295 & 1655 & 10 & 314 & 23 & -21.3 \\
OZE980 & 285 & 1665 & 10 & 236 & 22 & -20.6 \\
OZE981 & 275 & 1675 & 10 & 203 & 21 & -20.5 \\
OZE982 & 265 & 1685 & 10 & 176 & 23 & -20.7 \\
OZE983 & 255 & 1695 & 10 & 179 & 23 & -20.7 \\
OZE984 & 245 & 1705 & 10 & 139 & 21 & -21.5 \\
OZE985 & 235 & 1715 & 10 & 167 & 22 & -20.4 \\
OZE986 & 225 & 1725 & 10 & 166 & 25 & -20.4 \\
OZE987 & 215 & 1735 & 10 & 220 & 21 & -19.9 \\
OZE988 & 205 & 1745 & 10 & 226 & 23 & -20.0 \\
OZF932 & 195 & 1755 & 10 & 258 & 25 & -20.4 \\
OZF933 & 185 & 1765 & 10 & 226 & 21 & -21.4 \\
OZF934 & 175 & 1775 & 10 & 194 & 24 & -20.6 \\
\hline
\end{tabular}

Vries acid-base-acid method. The data showed a similar structure to the $\mathrm{NH}$ curve but are generally older, with a distinct but variable offset to IntCal04 (Reimer et al. 2004) averaging $42 \pm 26$ yr. They report a zero interhemispheric offset for an 80-yr period (1175-1095 cal BP; AD 775-855) but also note the need to replicate these data to confirm this. Although the interhemispheric offset calculated from the CAMS data utilizes IntCal04 and not IntCal09 (Reimer et al. 2009) as used for the Wk data by Hogg et al. (2011), the calculated offsets are directly comparable as the IntCal04 and IntCal09 data sets are identical for the late Holocene.

The CAMS Huon data set is compiled from a total of 222 measurements, including repeat determinations, analyzed over $\sim 3.5 \mathrm{yr}$, with the first set of 40 measurements $(\sim 18 \%$ of the 222 individual analyses made) analyzed with protocols designed to ensure higher levels of precision, with standard errors typically $\pm 15 \mathrm{yr}$ ( $\mathrm{T}$ Guilderson, personal communication). The remaining 182 measurements did not follow the same protocols and are less precise, with the standard errors as reported by Zimmerman et al. (2010) considered too low (Hogg et al. 2011). To check the findings of Hogg et al. (2011), and with the added advantage of having CAMS individual measurements, the standard errors of the CAMS Huon data set were re-assessed independently by Quan Hua, using the methods outlined below.

According to Scott et al. (2007) and Russell et al. (2011), the quoted error associated with a single analysis should be comparable to the standard deviation of the reference standards, with TIRI wood, Belfast cellulose, and Irish oak (Q1323) utilized in the CAMS study. The population standard deviations of these standards are $28 \mathrm{yr}$ (11 analyses), $34 \mathrm{yr}$ (11 analyses), and $26 \mathrm{yr}$ (18 analyses), respectively. The average value of these standard deviations is $29 \mathrm{yr}$, which is much larger than most of the original errors quoted for single CAMS Huon measurements. We have therefore assigned a minimum value of $\pm 29 \mathrm{yr}$ for single analyses from the lower-precision data set, while retaining the \pm 15 yr errors for the higher-precision data. 
Although more than half of the decadal samples were replicated, the methods Zimmerman et al. (2010) used to calculate a decadal weighted mean $\left(X_{\text {mean }}\right.$ in Equation 1$)$ and its associated error $\left(E_{\text {stat }}\right.$ in Equation 2) did not take into account the scatter of the data:

$$
\begin{gathered}
\mathrm{X}_{\text {mean }}=\left(\Sigma \frac{\mathrm{X}_{\mathrm{i}}}{\mathrm{E}_{\mathrm{i}}^{2}}\right) /\left(\Sigma \frac{1}{\mathrm{E}_{\mathrm{i}}^{2}}\right) \\
\mathrm{E}_{\text {stat }}=\sqrt{1 / \Sigma \frac{1}{\mathrm{E}_{\mathrm{i}}^{2}}}
\end{gathered}
$$

where $\mathrm{X}_{\mathrm{i}}$ and $\mathrm{E}_{\mathrm{i}}$ are ${ }^{14} \mathrm{C}$ age and its associated uncertainty for each single measurement, respectively.

To calculate a standard error that does take into account the dispersion of the data for each replicated sample, we have used Equation 3 (see Burr et al. 2007):

$$
\mathrm{E}_{\mathrm{std}}=\sqrt{\frac{\Sigma\left(\left(\mathrm{X}_{\mathrm{i}}-\mathrm{X}_{\text {mean }}\right)^{2} / \mathrm{E}_{\mathrm{i}}^{2}\right)}{(\mathrm{n}-1) \Sigma\left(1 / \mathrm{E}_{\mathrm{i}}^{2}\right)}}
$$

Using this method, the error $\left(\mathrm{E}_{\text {final }}\right)$ associated with each replicated sample is the larger of $\mathrm{E}_{\text {stat }}$ and $\mathrm{E}_{\mathrm{std}}$. The CAMS data set with revised errors is reported in Table 2. In addition to the higher errors, 14 decadal measurements are likely to be erroneous and have been omitted (see discussion below).

Table 2 Revised CAMS measurements on Tasmanian Huon pine: $2115-855 \mathrm{cal}$ BP (165 BC-AD 1095). Original data from Zimmerman et al. (2010). $\mathrm{E}_{\text {final }}{ }^{14} \mathrm{C}$ error for replicated samples is the larger of $\mathrm{E}_{\text {stat }}\left(\right.$ Equation 2) and $\mathrm{E}_{\text {std }}$ (Equation 3 ).

\begin{tabular}{llll}
\hline $\begin{array}{l}\text { yr BP } \\
\text { (midpoint) }\end{array}$ & $\begin{array}{l}\text { yr AD } \\
\text { (midpoint) }\end{array}$ & $\begin{array}{l}{ }^{14} \mathrm{C} \text { age } \\
(\mathrm{BP})\end{array}$ & $\begin{array}{l}{ }^{14} \mathrm{C} \text { error } \\
\left(\mathrm{E}_{\text {final }}\right)\end{array}$ \\
\hline 2115 & -165 & 2170 & 29 \\
2105 & -155 & 2160 & 29 \\
2095 & -145 & 2144 & 20 \\
2085 & -135 & 2150 & 29 \\
2075 & -125 & 2123 & 11 \\
2065 & -115 & 2165 & 21 \\
2055 & -105 & 2122 & 12 \\
2045 & -95 & 2135 & 29 \\
2035 & -85 & 2104 & 10 \\
2025 & -75 & 2118 & 27 \\
2015 & -65 & 2100 & 21 \\
2005 & -55 & 2113 & 21 \\
1995 & -45 & 2049 & 10 \\
1985 & -35 & 2013 & 21 \\
1975 & -25 & 2018 & 28 \\
1965 & -15 & 2040 & 29 \\
1955 & -5 & 2040 & 15 \\
1945 & 5 & 2065 & 21 \\
1935 & 15 & 2055 & 15 \\
1925 & 25 & 2025 & 29 \\
1915 & 35 & 1995 & 15 \\
1905 & 45 & 2015 & 29
\end{tabular}


Table 2 Revised CAMS measurements on Tasmanian Huon pine: 2115-855 cal BP (165 BC-AD 1095). Original data from Zimmerman et al. (2010). $\mathrm{E}_{\text {final }}{ }^{14} \mathrm{C}$ error for replicated samples is the larger of $\mathrm{E}_{\text {stat }}$ (Equation 2) and $\mathrm{E}_{\text {std }}$ (Equation 3). (Continued)

\begin{tabular}{|c|c|c|c|}
\hline $\begin{array}{l}\text { yr BP } \\
\text { (midpoint) }\end{array}$ & $\begin{array}{l}\mathrm{yr} \mathrm{AD} \\
\text { (midpoint) }\end{array}$ & $\begin{array}{l}{ }^{14} \mathrm{C} \text { age } \\
(\mathrm{BP})\end{array}$ & $\begin{array}{l}{ }^{14} \mathrm{C} \text { error } \\
\left(\mathrm{E}_{\text {final }}\right)\end{array}$ \\
\hline 1895 & 55 & 2012 & 24 \\
\hline 1885 & 65 & 1975 & 29 \\
\hline 1875 & 75 & 1950 & 15 \\
\hline 1865 & 85 & 1940 & 21 \\
\hline 1855 & 95 & 1940 & 11 \\
\hline 1845 & 105 & 1969 & 17 \\
\hline 1835 & 115 & 1945 & 15 \\
\hline 1825 & 125 & 1890 & 29 \\
\hline 1815 & 135 & 1895 & 11 \\
\hline 1805 & 145 & 1875 & 29 \\
\hline 1795 & 155 & 1865 & 15 \\
\hline 1785 & 165 & 1882 & 17 \\
\hline 1775 & 175 & 1850 & 15 \\
\hline 1765 & 185 & 1921 & 21 \\
\hline 1755 & 195 & 1905 & 11 \\
\hline 1745 & 205 & 1880 & 31 \\
\hline 1735 & 215 & 1861 & 10 \\
\hline 1725 & 225 & 1860 & 30 \\
\hline 1715 & 235 & 1846 & 13 \\
\hline 1705 & 245 & 1840 & 22 \\
\hline 1695 & 255 & 1755 & 12 \\
\hline 1685 & 265 & 1773 & 28 \\
\hline 1675 & 275 & 1770 & 11 \\
\hline 1665 & 285 & 1780 & 22 \\
\hline 1655 & 295 & 1774 & 13 \\
\hline 1645 & 305 & 1815 & 35 \\
\hline 1635 & 315 & 1804 & 12 \\
\hline 1625 & 325 & 1805 & 29 \\
\hline 1615 & 335 & 1805 & 15 \\
\hline 1605 & 345 & 1730 & 21 \\
\hline 1595 & 355 & 1760 & 11 \\
\hline 1585 & 365 & 1715 & 18 \\
\hline 1575 & 375 & 1715 & 15 \\
\hline 1565 & 385 & 1715 & 21 \\
\hline 1555 & 395 & 1680 & 15 \\
\hline 1545 & 405 & 1738 & 21 \\
\hline 1535 & 415 & 1695 & 29 \\
\hline 1525 & 425 & 1675 & 29 \\
\hline 1515 & 435 & 1643 & 17 \\
\hline 1505 & 445 & 1625 & 29 \\
\hline 1495 & 455 & 1635 & 29 \\
\hline 1485 & 465 & 1638 & 23 \\
\hline 1475 & 475 & 1623 & 28 \\
\hline 1465 & 485 & 1645 & 29 \\
\hline 1455 & 495 & 1613 & 21 \\
\hline 1445 & 505 & 1615 & 21 \\
\hline 1435 & 515 & 1665 & 29 \\
\hline 1425 & 525 & 1603 & 21 \\
\hline 1415 & 535 & 1605 & 29 \\
\hline 1405 & 545 & 1568 & 28 \\
\hline 1395 & 555 & 1555 & 21 \\
\hline
\end{tabular}


Table 2 Revised CAMS measurements on Tasmanian Huon pine: $2115-855$ cal BP (165 BC-AD 1095). Original data from Zimmerman et al. (2010). $\mathrm{E}_{\text {final }}{ }^{14} \mathrm{C}$ error for replicated samples is the larger of $\mathrm{E}_{\text {stat }}$ (Equation 2) and $\mathrm{E}_{\text {std }}$ (Equation 3). (Continued)

\begin{tabular}{|c|c|c|c|}
\hline $\begin{array}{l}\text { yr BP } \\
\text { (midpoint) }\end{array}$ & $\begin{array}{l}\mathrm{yr} \mathrm{AD} \\
\text { (midpoint) }\end{array}$ & $\begin{array}{l}{ }^{14} \mathrm{C} \text { age } \\
(\mathrm{BP})\end{array}$ & $\begin{array}{l}{ }^{14} \mathrm{C} \text { error } \\
\left(\mathrm{E}_{\text {final }}\right)\end{array}$ \\
\hline 1385 & 565 & 1560 & 29 \\
\hline 1375 & 575 & 1553 & 43 \\
\hline 1365 & 585 & 1528 & 19 \\
\hline 1355 & 595 & 1495 & 29 \\
\hline 1345 & 605 & 1480 & 29 \\
\hline 1335 & 615 & 1480 & 21 \\
\hline 1325 & 625 & 1513 & 15 \\
\hline 1315 & 635 & 1500 & 29 \\
\hline 1305 & 645 & 1440 & 29 \\
\hline 1295 & 655 & 1392 & 21 \\
\hline 1285 & 665 & 1405 & 29 \\
\hline 1275 & 675 & 1378 & 21 \\
\hline 1265 & 685 & 1318 & 21 \\
\hline 1255 & 695 & 1308 & 21 \\
\hline 1245 & 705 & 1335 & 29 \\
\hline 1235 & 715 & 1315 & 29 \\
\hline 1225 & 725 & 1305 & 29 \\
\hline 1215 & 735 & 1300 & 21 \\
\hline 1065 & 885 & 1200 & 30 \\
\hline 1055 & 895 & 1195 & 25 \\
\hline 1045 & 905 & 1140 & 21 \\
\hline 1035 & 915 & 1140 & 29 \\
\hline 1025 & 925 & 1185 & 29 \\
\hline 1015 & 935 & 1163 & 21 \\
\hline 1005 & 945 & 1180 & 29 \\
\hline 995 & 955 & 1200 & 29 \\
\hline 985 & 965 & 1145 & 21 \\
\hline 975 & 975 & 1135 & 29 \\
\hline 965 & 985 & 1160 & 29 \\
\hline 955 & 995 & 1035 & 29 \\
\hline 945 & 1005 & 1113 & 33 \\
\hline 935 & 1015 & 1075 & 21 \\
\hline 925 & 1025 & 1025 & 60 \\
\hline 915 & 1035 & 965 & 29 \\
\hline 905 & 1045 & 980 & 29 \\
\hline 895 & 1055 & 1025 & 29 \\
\hline 885 & 1065 & 1025 & 29 \\
\hline 875 & 1075 & 945 & 29 \\
\hline 865 & 1085 & 985 & 29 \\
\hline 855 & 1095 & 940 & 29 \\
\hline
\end{tabular}

Waikato Measurements of New Zealand Kauri (2145-955 cal BP)

Hogg et al. (2011) reported 120 high-precision measurements on dendrochronologically secure decadal kauri samples from the Maitahi and Harding sites in Northland, New Zealand, for the interval 2145-955 cal BP (195 BC-AD 995). The analyses were made at the University of Waikato by liquid scintillation spectroscopy using LKB Wallac Quantulus ${ }^{\mathrm{TM}} 1220$ spectrometers with laboratory protocols and counting parameters optimized for high-precision measurement. All samples were pretreated to $\alpha$-cellulose, comprising a 4-step process including solvent extraction, bleaching with 
acidified $\mathrm{NaClO}_{2}, \mathrm{NaOH}$ extraction, and acidification with $\mathrm{HCl}$. The Waikato kauri data set has an average offset to IntCal09 of $48 \pm 2 \mathrm{yr}$ and varies between -5 and $100 \mathrm{yr}$.

\section{Waikato Measurements of Huon Pine (1205-1075 cal BP)}

While the CAMS measurements showed a zero interhemispheric offset for the interval 1175-1095 cal BP, the Wk kauri measurements found a consistent offset ( $48 \mathrm{yr}$ ) with IntCal09 (Reimer et al. 2009) over the entire 1200-yr range of the measurements. To investigate the discrepancies between these 2 data sets and the possibility of real differences in atmospheric ${ }^{14} \mathrm{C}$ concentration between Tasmania and Northland from 1175-1095 cal BP (the period showing the largest Huon-kauri differences), the Waikato laboratory measured 9 decadal Tasmanian Huon pine samples from SRT-440, the same Huon pine tree used by Zimmerman et al. (2010). As with previous Waikato measurements, samples were pretreated to $\alpha$-cellulose, with the same measurement protocols used to determine the kauri data set. The 9 Waikato Huon measurements are $53 \pm 7 \mathrm{yr}$ older than the equivalent CAMS Huon data but only $4 \pm 8$ yr older than the equivalent Waikato kauri data (Hogg et al. 2013a, this issue), and we agree with the authors who concluded it was unlikely that a local offset exists between Tasmania and New Zealand. Given the consistency of the interhemispheric offset for New Zealand wood (New Zealand kauri, cedar, and silver pine) over the last $2000 \mathrm{yr}$, and the Waikato measurements of Tasmanian Huon pine, we concur with Hogg et al. (2011) that the younger 11751095 cal BP CAMS Huon data are likely to be incorrect. Indeed, as a result of our re-assessment of these SH data sets, we consider 14 CAMS Huon decadal analyses (1205-1075 cal BP) are erroneous and these have been omitted in Table 2. The revised CAMS Huon data set has an average offset to IntCal09 of $42 \pm 2 \mathrm{yr}$ and a range of -12 to $113 \mathrm{yr}$. The Waikato kauri measurements are on average $4 \pm 3$ yr older than the revised CAMS Huon measurements.

\section{$\sim 12,100-12,700$ cal BP}

Hua et al. (2009) obtained 134 high-precision measurements from 4 Tasmanian Huon pine subfossil logs extracted from alluvial sediments along Stanley River in NW Tasmania, Australia, spanning the time interval 10,350 to $10,760{ }^{14} \mathrm{C}$ yr BP. The AMS measurements were obtained from wood pretreated to $\alpha$-cellulose (Hua et al. 2004) at ANSTO using the ANTARES facility. Spectroscopicgrade powdered graphite from Union Carbide Corporation was used as blank material for evaluating accelerator and chemistry backgrounds. The original or unprocessed graphite (UPG) was employed for estimating accelerator background, while a mass-dependent chemistry blank was derived from processed (combusted and graphitized) graphite (PG) of different sizes. For every 15 samples, 2 blanks (1 UPG and 1 PG) were included for AMS measurement. The typical analytical AMS precision was $0.3-0.4 \%$, including standard normalization and corrections for backgrounds (accelerator and chemistry) and isotopic fractionation using measured $\delta^{13} \mathrm{C}$. Although each of the 4 subfossil logs showed clearly defined and measured annual tree rings, the logs could not be uniquely crossmatched by ring-width correlations alone. ${ }^{14} \mathrm{C}$ wiggle-matching was therefore used to supplement ring-width data to correlate the 4 logs and produce a 617 -yr-long floating chronology. The timespan of the floating Huon chronology of $12,679 \pm 11$ to $12,072 \pm 11$ cal BP was determined by linking it to the $\mathrm{NH}$ extended absolute tree-ring chronology using ${ }^{14} \mathrm{C}$ wiggle-matching with a 40 -yr constant interhemispheric offset.

Hogg et al. (2013b, this issue) recently reported a new initiative to obtain atmospheric ${ }^{14} \mathrm{C}$ data from kauri tree rings for the time interval $\sim 13,100-11,700$ cal BP. Initial intercalibration studies for this project showed that the calendar position of the Swiss larch sequence Ollon (VOD) 505 in IntCal04 and IntCal09 might not be correct. While the extended NH tree-ring series is dendro-dated independent of VOD505, this series did make an important contribution to the shape of IntCal between 
$\sim 12,130-11,950$ cal BP. The VOD505 shift indicates that YD ${ }^{14} \mathrm{C}$ calibration data based on tree-ring series are still a work in progress. Future work to strengthen ${ }^{14} \mathrm{C}$ and dendrochronology in both $\mathrm{NH}$ and $\mathrm{SH}$ sequences could produce additional decadal-scale changes affecting the positioning of the Hua et al. (2009) Huon data set.

\section{CALIBRATION CURVE CONSTRUCTION}

\section{Measured SH Curve}

The new SH calibration curve utilizes the SH data sets incorporated into SHCal04 from 0-1000 cal BP and ANSTO Huon data from 325-175 cal BP, and extended to $2145 \mathrm{cal} \mathrm{BP}$ with the Waikato kauri and Huon data sets and modified CAMS Huon data set (Figures 1A and B).

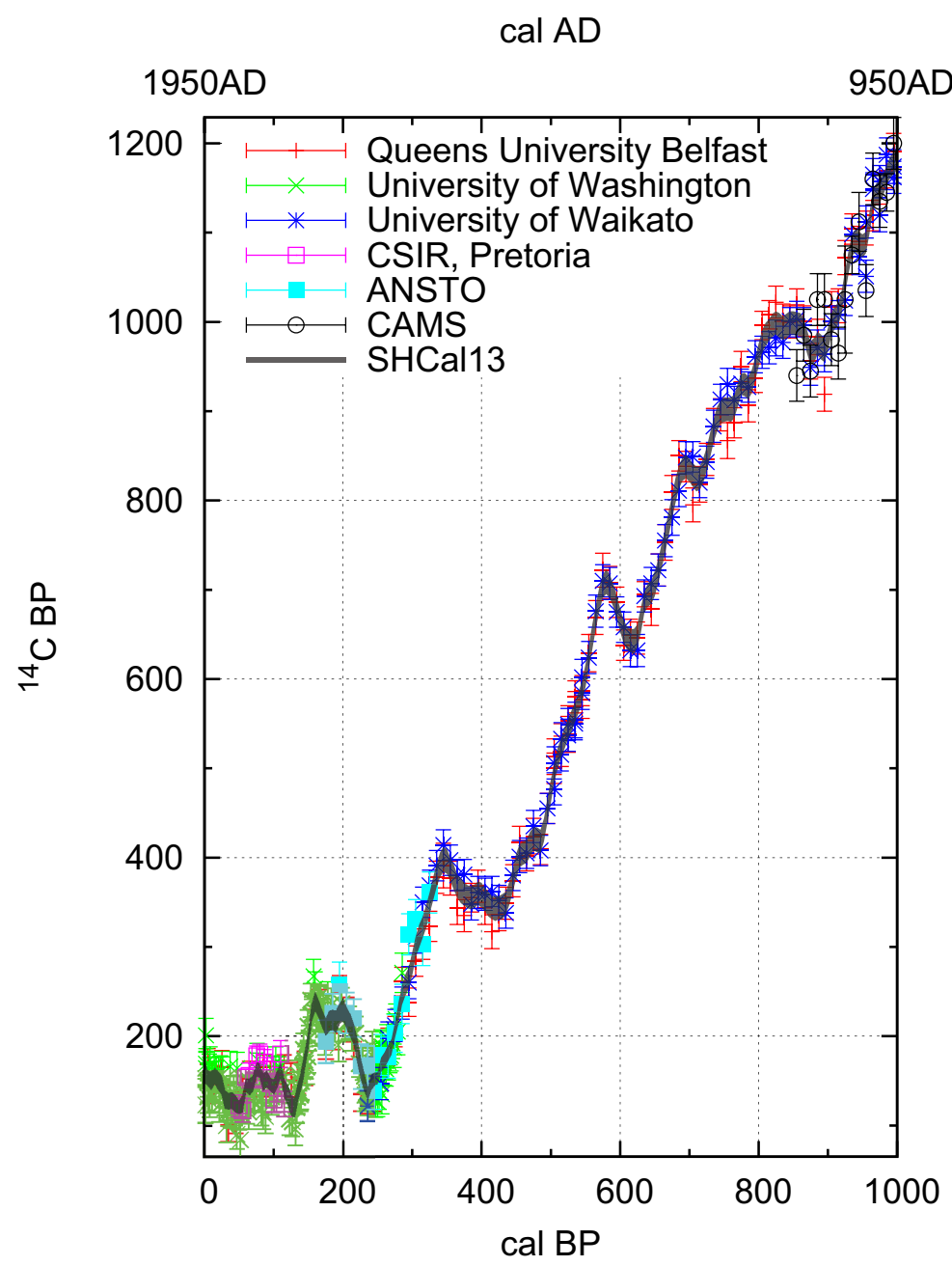

Figure 1A SHCal13 terrestrial calibration curve (1-standard deviation envelope) and data with 1-standard deviation uncertainty in the ${ }^{14} \mathrm{C}$ and calendar ages. Color-coded individual data sets can be seen in the online version of this article. 


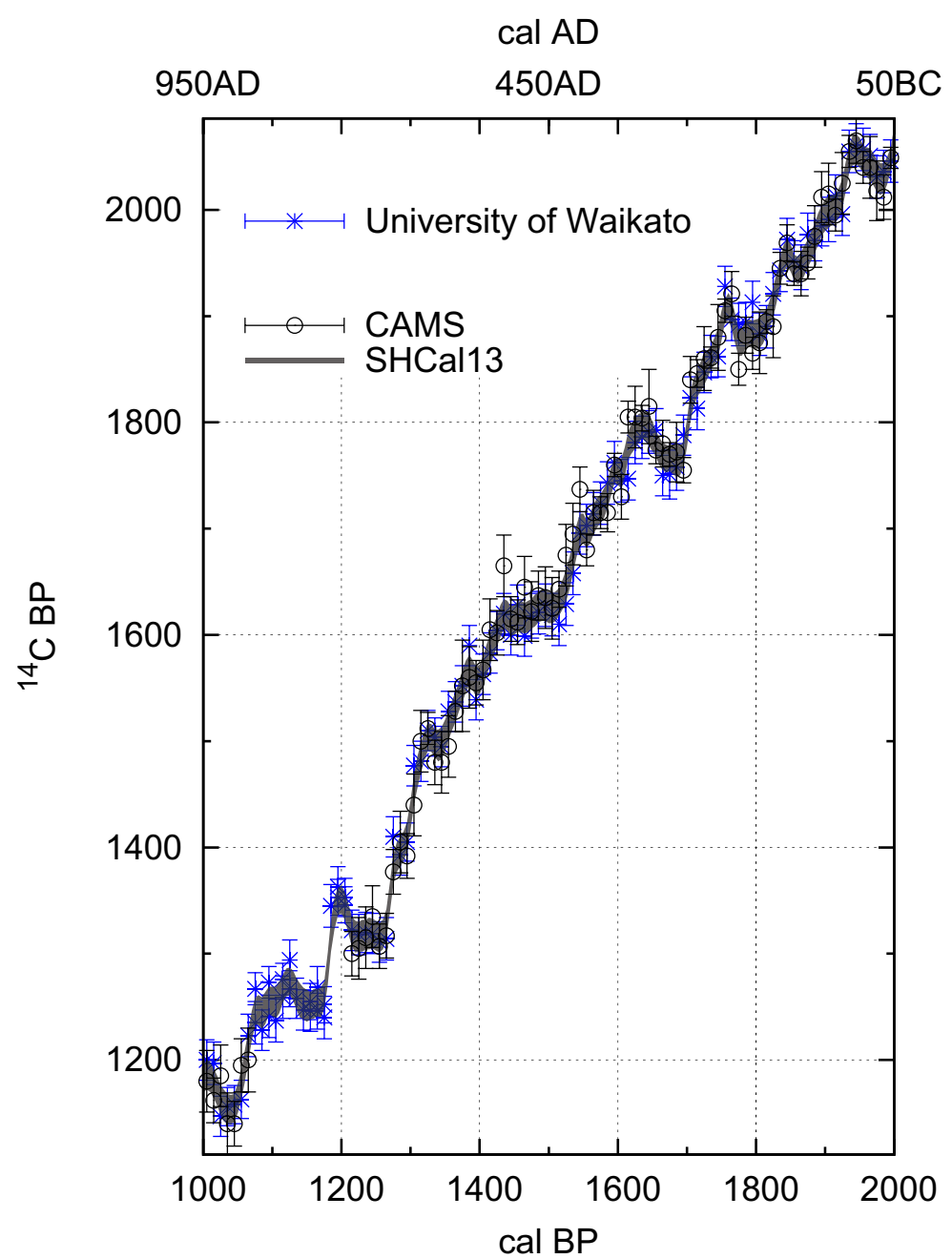

Figure 1B SHCal13 terrestrial calibration curve (1-standard deviation envelope) and data with 1-standard deviation uncertainty in the ${ }^{14} \mathrm{C}$ and calendar ages. Color-coded individual data sets can be seen in the online version of this article.

The new SH curve also uses the measured ANSTO YD Huon data set from 12,679 \pm 11 to $12,072 \pm$ 11 cal BP (Figure 2), inserted into the modeled reconstruction (see below), using transitional regions where the variance depends upon both the ANSTO data and the modeled SH data.

The underlying calibration curve was constructed using the same approach as IntCal13, using a Markov chain Monte Carlo (MCMC) implementation of the random walk model (Blackwell and Buck 2008; Heaton et al. 2009; Niu et al. 2013, this issue).

\section{Modeled Southern Hemisphere Curve}

Beyond the range of the measured data sets, SHCal13 is based upon NH data as given in IntCal13, corrected for an interhemispheric offset, which results in contemporaneous SH dates being older than NH dates by a few decades. 


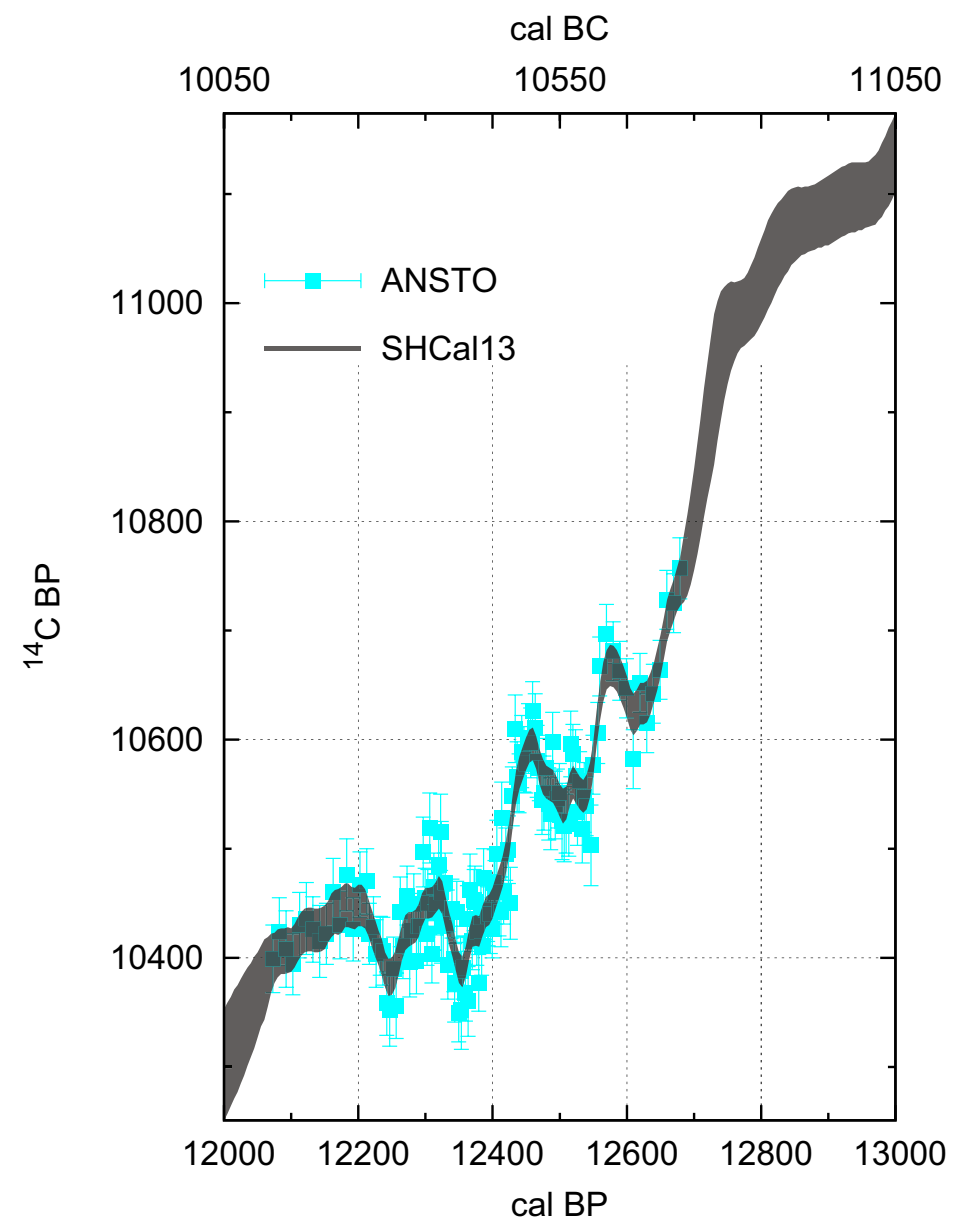

Figure 2 SHCal13 terrestrial calibration curve (1-standard deviation envelope) and data with 1-standard deviation uncertainty in the ${ }^{14} \mathrm{C}$ and calendar ages. Colorcoded individual data sets can be seen in the online version of this article.

\section{Value of the Interhemispheric Offset}

The interhemispheric ${ }^{14} \mathrm{C}$ offset has been variously measured at 8 to $80{ }^{14} \mathrm{C}$ yr for the last $1000 \mathrm{yr}$ (average $=41 \pm 14 \mathrm{yr}$; McCormac et al. 2002) to -2 to $83{ }^{14} \mathrm{C}$ yr for the last $\sim 2000 \mathrm{yr}$ (average $=44 \pm$ $17 \mathrm{yr}$; Hogg et al. 2011). Kromer et al. (1998) and Barbetti et al. (2004) measured floating early Holocene Tasmanian Huon pine and German oak-pine tree rings and also found interhemispheric offset ranges from 0-100 yr. Hogg et al. (2009) determined the interhemispheric offset in 4 accurate and precise SH data sets between 7300 and $10,200{ }^{14} \mathrm{C}$ yr BP, and found offset levels of $\sim 50 \mathrm{yr}$.

The 617-yr-long early YD Huon pine chronology of Hua et al. (2009) was used to link the floating NH pre-YD Late Glacial Pine Chronology (Kromer et al. 2004) with the NH extended absolute treering chronology (Hua et al. 2009). The authors subtracted $40 \mathrm{yr}$ from the Huon measurements to account for the interhemispheric offset and found a smooth transition between the $\mathrm{NH}$ and SH data sets. Their conclusion, that ocean circulation reorganization was mainly responsible for the onset of the YD, makes an unchanging interhemispheric offset all the more remarkable. It also provides some confidence that large-scale carbon reservoir changes may not have significantly impacted the 
interhemispheric ${ }^{14} \mathrm{C}$ offset before this time, as originally feared by McCormac et al. (2004), who limited SHCal04 to 11,000 cal BP for this reason.

For SHCal13, the offset has been estimated from the intervals where the SH curve is measured directly, by calculating the difference between the SH curve and IntCal13, at the 5-yearly "grid points" on which IntCal13 is reported. A stationary first-order autoregressive model (see e.g. Brockwell and Davis 2002) was then fitted to the differences, giving an estimated mean offset of $43 \mathrm{yr}$, with a standard deviation of $23 \mathrm{yr}$, broadly consistent with the range reported for 2150-100 cal BP by Hogg et al. (2011).

Although the variability in the offset (SHCal13 minus IntCal13) for the interval 0-2000 cal BP accurately reflects changes in the distribution of ${ }^{14} \mathrm{C}$ between the hemispheres because all measurements are derived from dendrochronologically secure chronologies, this may not be the case for the interval 12,000-13,000 cal BP. SH data may contain extra noise as the Tasmanian Huon pine chronology is mainly based upon ${ }^{14} \mathrm{C}$ wiggle-matching and, in addition, the $\mathrm{NH}$ data sets have a paucity of measurements around 12,250 and 12,600 cal BP (B Kromer, personal communication). We would therefore warn against a literal interpretation of the interhemispheric offset distribution for the YD as derived from SHCal13 and IntCal13.

\section{Offsetting IntCal13}

For calendar ages that are far from the direct measurements of the SH curve, we constructed SHCal13 by adjusting the mean for IntCal13 by the mean offset calculated above; the uncertainty on SHCal was obtained by adding the uncertainty on the offset to the uncertainty on IntCal (adding variances, or equivalently adding standard deviations "in quadrature").

For calendar ages that are outside, but close to, the directly measured ranges, we have additional information on the offset, since it varies relatively slowly. We used the fitted autoregressive model, and the local value of the offset estimated from the direct measurements, to obtain predictions of the offset nearby, with associated uncertainty; these were used to offset IntCal13, as above. Further back in time from the direct measurements, the local estimate of the offset tends towards a value approximating the long-term estimate of $43 \mathrm{yr}$, and the uncertainty in the prediction increases, eventually reaching the long-term standard deviation of $23 \mathrm{yr}$. Thus, this modeling and prediction of the offset provides a statistically principled way of achieving a smooth transition between direct and indirect estimation of the SH curve. For further details, see Niu et al. (2013, this issue).

Figure 3 shows an example at $2145 \mathrm{cal} \mathrm{BP}$, where the main direct measurements of the SH curve come to an end. The curve is estimated purely from SH data back to $2145 \mathrm{cal} \mathrm{BP}$, where the offset is approximately $29 \mathrm{yr}$. Beyond that, the offset is predicted from the fitted model, with the uncertainty increasing as we look further beyond the direct data. This modeling of the offset has an effect over a period of roughly $250 \mathrm{yr}$; so for the part of the plot beyond about $2400 \mathrm{cal} \mathrm{BP}$, SHCal13 is essentially IntCal13 adjusted by $43 \mathrm{yr}$.

\section{Range of SHCal13}

Following the lead shown by IntCal09 (Reimer et al. 2009) and IntCal13 (Reimer et al. 2013, this issue), we have extended SH calibration to $50,000 \mathrm{cal} \mathrm{BP}$, assuming interhemispheric offset levels similar to those measured for the past $\sim 2000 \mathrm{yr}$. However, we also note that a significant component of the pre-YD ${ }^{14} \mathrm{C}$ data sets are compiled from surface ocean-based records, which are subject to errors resulting from changes in marine reservoir ages $(R)$. With this caveat, the IWG has generated 
a new SH calibration curve back to $50,000 \mathrm{cal} \mathrm{BP}$, with ratification by the international carbon dating community at the 21 st International Radiocarbon Conference.

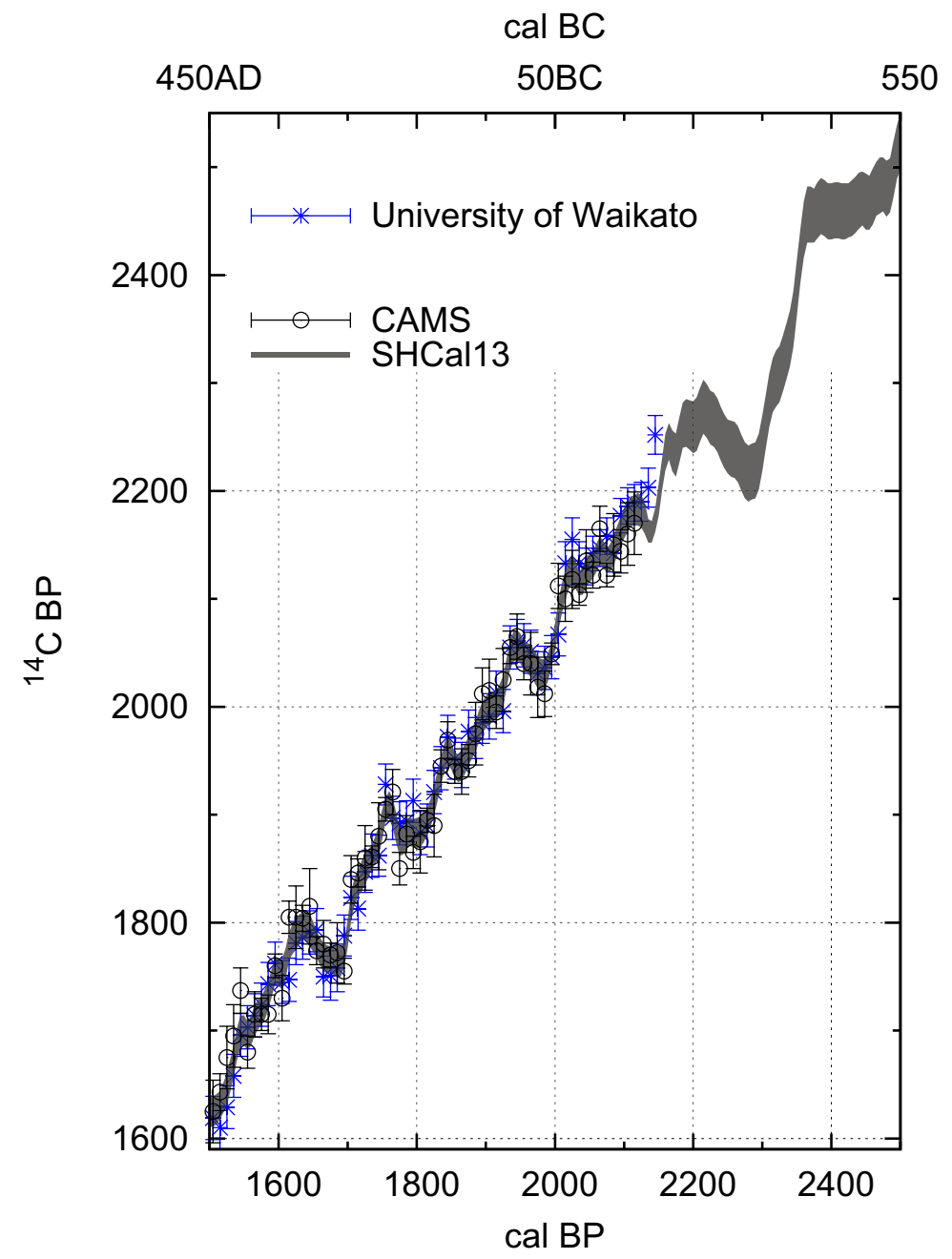

Figure 3 SHCal13 terrestrial calibration curve (1-standard deviation envelope) and data with 1-standard deviation uncertainty in the ${ }^{14} \mathrm{C}$ and calendar ages. The calibration curve beyond the end of the tree-ring data set at $2145 \mathrm{cal} \mathrm{BP}$ (but excluding the YD data shown in Figure 2) is based on the offset from the NH data set (IntCal13) calculated with a random effects model (see text for more details). Color-coded individual data sets can be seen in the online version of this article.

\section{FUTURE RESEARCH}

Following McCormac et al. (2004), we define the NH-SH boundary as south of the Intertropical Convergence Zone (ITCZ), which experiences seasonal shifts of atmospheric $\mathrm{CO}_{2}$, creating additional uncertainties in ${ }^{14} \mathrm{C}$ calibration in tropical or neotropical sites. Further research is needed to identify the most appropriate curves for these regions and funding agencies should be encouraged to support this work. 


\section{ACKNOWLEDGMENTS}

Thanks to Dr John Southon (Keck laboratory UCI) and Drs Warren Beck and George Burr (University of Arizona) for helpful comments in their reviews of this paper.

\section{REFERENCES}

Barbetti M, Hua Q, Zoppi U, Fink D, Zhao Y, Thomson B. 2004. Radiocarbon variations from the Southern Hemisphere, 10,350-9700 cal BP. Nuclear Instruments and Methods in Physics Research B 223-224: 366-70.

Blackwell P, Buck C. 2008. Estimating radiocarbon calibration curves. Bayesian Analysis 3(2):225-48.

Brockwell P, Davis R. 2002. Introduction to Time Series and Forecasting. 2nd edition. New York: Springer.

Buck C, Blackwell P. 2004. Formal statistical models for estimating radiocarbon calibration curves. Radiocarbon 46(3):1093-102.

Burr GS, Donahue DJ, Tang Y, Beck W, McHargue L, Biddulph D, Cruz R, Jull AJT. 2007. Error analysis at the NSF-Arizona AMS facility. Nuclear Instruments and Methods in Physics Research B 259(1):149-53.

Heaton TJ, Blackwell PG, Buck CE. 2009. A Bayesian approach to the estimation of radiocarbon calibration curves: the IntCal09 methodology. Radiocarbon 51(4):1151-64.

Hogg AG, McCormac FG, Higham TFG, Reimer PJ, Baillie MGL, Palmer JG. 2002. High-precision radiocarbon measurements of contemporaneous tree-ring dated wood from the British Isles and New Zealand: AD 1850-950. Radiocarbon 44(3):633-40.

Hogg A, Bronk Ramsey C, Turney C, Palmer J. 2009. Bayesian evaluation of the Southern Hemisphere radiocarbon offset during the Holocene. Radiocarbon 51(4):1165-76.

Hogg A, Palmer J, Boswijk G, Turney C. 2011. High-precision radiocarbon measurements of tree-ring dated wood from New Zealand: 195 BC-AD 995. Radiocarbon 53(3):529-42.

Hogg A, Turney C, Palmer J, Cook E, Buckley B. 2013a. Is there any evidence for regional ${ }^{14} \mathrm{C}$ offsets in the Southern Hemisphere? Radiocarbon 55(4), this issue.

Hogg A, Turney C, Palmer J, Southon J, Kromer B, Bronk Ramsey C, Boswijk G, Fenwick P, Noronha A, Staff R, Friedrich M, Reynard L, Guetter D, Wacker L, Jones R. 2013b. The New Zealand kauri (Agathis Australis) research project: a radiocarbon dating intercomparison of Younger Dryas wood and implications for IntCal13. Radiocarbon 55(4), this issue.

Hua Q, Barbetti M, Zoppi U, Fink D, Watanasak M, Jacobsen G. 2004. Radiocarbon in tropical tree rings during the Little Ice Age. Nuclear Instruments and Methods in Physics Research B 223-224:489-94.

Hua Q, Barbetti M, Fink D, Kaiser K, Friedrich M, Kromer B, Levchenko V, Zoppi U, Smith A, Bertuch F. 2009. Atmospheric ${ }^{14} \mathrm{C}$ variations derived from tree rings during the early Younger Dryas. Quaternary Sci- ence Reviews 28(25-26):2982-990.

Kromer B, Spurk M, Remmele S, Barbetti M. 1998. Segments of atmospheric ${ }^{14} \mathrm{C}$ change as derived from late glacial and early Holocene floating tree-ring series. Radiocarbon 40(1):351-8.

Kromer B, Friedrich M, Hughen KA. Kaiser KF, Remmele S, Schaub M, Talamo S. 2004. Late glacial ${ }^{14} \mathrm{C}$ ages from a floating, 1382-ring pine chronology. $R a-$ diocarbon 46(3):1203-9.

McCormac FG, Hogg AG, Higham TFG, Lynch-Stieglitz J, Broecker WS, Baillie MGL, Palmer J, Xiong L, Pilcher JR, Brown D, Hoper ST. 1998. Temporal variation in the interhemispheric ${ }^{14} \mathrm{C}$ offset. Geophysical Research Letters 25(9):1321-4.

McCormac G, Reimer P, Hogg A, Higham T, Baillie M, Palmer J, Stuiver M. 2002. Calibration of the radiocarbon time scale for the Southern Hemisphere AD 1850-950. Radiocarbon 44(3):641-51.

McCormac G, Hogg A, Blackwell P, Buck C, Higham T, Reimer P. 2004. SHCal04 Southern Hemisphere calibration, 0-11.0 cal kyr BP. Radiocarbon 46(3):108792.

Mook WG. 1986. Business meeting: recommendations/ resolutions adopted by the Twelfth International ${ }^{14} \mathrm{C}$ Conference. Radiocarbon 28(2A):799.

Niu M, Heaton TJ, Blackwell PG, Buck CE. 2013. The Bayesian approach to radiocarbon calibration curve estimation: the IntCal13, Marine13, and SHCal13 methodologies. Radiocarbon 55(4), this issue.

Reimer PJ, Baillie MGL, Bard E, Bayliss A, Beck WJ, Bertrand C, Blackwell PG, Buck CE, Burr GS, Cutler KB, Damon PE, Edwards RL, Fairbanks RG, Friedrich M, Guilderson TP, Hughen KA, Kromer B, McCormac FG, Manning S, Bronk Ramsey C, Reimer RW, Remmele S, Southon JR, Stuiver M, Talamo S, Taylor FW, van der Plicht J, Weyhenmeyer CE. 2004. IntCal04 terrestrial radiocarbon age calibration, 0-26 cal kyr BP. Radiocarbon 46(3):1029-58.

Reimer PJ, Baillie MGL, Bard E, Bayliss A, Beck JW, Blackwell PG, Bronk Ramsey C, Buck CE, Burr GS, Edwards RL, Friedrich M, Grootes PM, Guilderson TP, Hajdas I, Heaton T, Hogg AG, Hughen KA, Kaiser KF, Kromer B, McCormac FG, Manning SW, Reimer RW, Richards DA, Southon JR, Talamo S, Turney CSM, van der Plicht J, Weyhenmeyer CE. 2009. IntCal09 and Marine09 radiocarbon age calibration curves, 0-50,000 years cal BP. Radiocarbon 51(4): 1111-50.

Reimer PJ, Bard E, Bayliss A, Beck JW, Blackwell PG, Bronk Ramsey C, Buck CE, Cheng H, Edwards RL, Friedrich M, Grootes PM, Guilderson TP, Haflidason 
H, Hajdas I, Hatté C, Heaton TJ, Hoffman DL, Hogg AG, Hughen KA, Kaiser KF, Kromer B, Manning SW, Niu M, Reimer RW, Richards DA, Scott EM, Southon JR, Staff RA, Turney CSM, van der Plicht J. 2013. IntCal13 and Marine13 radiocarbon age calibration curves $0-50,000$ years cal BP. Radiocarbon 55(4), this issue.

Rodgers KB, Mikaloff-Fletcher SE, Bianchi D, Beaulieu C, Galbraith ED, Gnanadesikan A, Hogg AG, Iudicone D, Lintner BR, Naegler T, Reimer PJ, Sarmiento JL, Slater RD. 2011. Interhemispheric gradient of atmospheric radiocarbon reveals natural variability of Southern Ocean winds. Climate of the Past 7:1123-38.

Russell N, Cook GT, Ascough PL, Scott EM, Dugmore AJ. 2011. Examining the inherent variability in $\Delta R$ : new methods of presenting $\Delta \mathrm{R}$ values and implications for MRE studies. Radiocarbon 53(2):277-88.
Scott EM, Cook GT, Naysmith P. 2007. Error and uncertainty in radiocarbon measurements. Radiocarbon 49(2):427-40.

Stuiver M, Braziunas TF. 1998. Anthropogenic and solar components of hemispheric ${ }^{14} \mathrm{C}$. Geophysical Research Letters 25(3):329-32.

Stuiver M, Reimer PJ, Bard E, Beck JW, Burr GS, Hughen KA, Kromer B, McCormac G, van der Plicht J, Spurk M. 1998. IntCal98 radiocarbon age calibration, 24,000-0 cal BP. Radiocarbon 40(3):1041-83.

Vogel JC, Fuls A, Visser E, Becker B. 1993. Pretoria calibration curve for short-lived samples, 1930-3350 BC. Radiocarbon 35(1):73-85.

Zimmerman S, Guilderson T, Buckley B, Cook E. 2010. Extension of the Southern Hemisphere atmospheric radiocarbon curve, 2120-850 years BP: results from Tasmanian Huon pine. Radiocarbon 52(2-3):887-94.

\section{APPENDIX: SOUTHERN HEMISPHERE CALIBRATION DATA SETS}

A summary of the ${ }^{14} \mathrm{C}$ data sets used for $\mathrm{SHCal13}$ is given below with references to the original data sets. These are cataloged by the institute where the ${ }^{14} \mathrm{C}$ measurements were made. Data set number is a historical construct and makes no reflection on the date of publication. Lab codes can be found on the Radiocarbon Web site at http://www.radiocarbon.org.

The SHCal13 database can be accessed at http://intcal.qub.ac.uk/shcal13/.

\section{CSIR, Pretoria (lab code: Pta)}

Data set number: 1

Tree rings from Cape Town pine tree.

Vogel JC, Fuls A, Visser E, Becker B. 1993. Pretoria calibration curve for short-lived samples, 1930-3350 BC. Radiocarbon 35(1):73-85.

\section{University of Washington (lab code: QL)}

Data set number: 2

Tree rings from Chilean coihue (Nothofagus dombeyi) and lenga (N. pumilio) and Tasmanian Huon pine (Lagarostrobos franklinii).

Stuiver M, Braziunas TF. 1998. Anthropogenic and solar components of hemispheric ${ }^{14} \mathrm{C}$. Geophysical Research Letters 25(3):329-32.

\section{University of Waikato (lab code: Wk)}

Data set number 3

Division 1: 0-1000 cal BP

Tree rings from New Zealand cedar (Libocedrus bidwillii) and silver pine (Lagarostrobos colensoi) chronology.

Hogg AG, McCormac FG, Higham TFG, Reimer PJ, Baillie MGL, Palmer JG. 2002. High-precision radiocarbon measurements of contemporaneous tree-ring dated wood from the British Isles and New Zealand: AD 1850-950. Radiocarbon 44(3):633-40. 
McCormac FG, Hogg AG, Higham TFG, Lynch-Stieglitz J, Broecker WS, Baillie MGL, Palmer J, Xiong L, Pilcher JR, Brown D, Hoper ST. 1998. Temporal variation in the interhemispheric ${ }^{14} \mathrm{C}$ offset. Geophysical Research Letters 25(9):1321-4.

Division 2: 2150-950 cal BP

Tree rings from New Zealand kauri (Agathis australis) chronology.

Hogg A, Palmer J, Boswijk G, Turney C. 2011. High-precision radiocarbon measurements of tree-ring dated wood from New Zealand: 195 BC-AD 995. Radiocarbon 53(3):529-42.

Division 3: 1205-1075 cal BP

Tree rings from Tasmanian Huon pine (Lagarostrobos franklinii) chronology.

Hogg A, Turney C, Palmer J, Cook E, Buckley B. 2013a. Is there any evidence for regional ${ }^{14} \mathrm{C}$ offsets in the Southern Hemisphere? Radiocarbon 55(4), this issue.

\section{Queen's University Belfast (lab code: UB)}

Data set number: 4

Tree rings from New Zealand cedar (Libocedrus bidwillii) and silver pine (Lagarostrobos colensoi) chronology.

Hogg AG, McCormac FG, Higham TFG, Reimer PJ, Baillie MGL, Palmer JG. 2002. High-precision radiocarbon measurements of contemporaneous tree-ring dated wood from the British Isles and New Zealand: AD 1850-950. Radiocarbon 44(3):633-40.

McCormac FG, Hogg AG, Higham TFG, Lynch-Stieglitz J, Broecker WS, Baillie MGL, Palmer J, Xiong L, Pilcher JR, Brown D, Hoper ST. 1998. Temporal variation in the interhemispheric ${ }^{14} \mathrm{C}$ offset. Geophysical Research Letters 25(9):1321-4.

\section{Australian Nuclear Science and Technology Organisation (lab code: $\mathrm{OZ}$ )}

Data set number: 5

Division 1: 12,100-12,700 cal BP

Tree rings from 4 Tasmanian Huon pine (Lagarostrobos franklinii) trees.

Hua Q, Barbetti M, Fink D, Kaiser K, Friedrich M, Kromer B, Levchenko V, Zoppi U, Smith A, Bertuch F. 2009. Atmospheric ${ }^{14} \mathrm{C}$ variations derived from tree rings during the early Younger Dryas. Quaternary Science Reviews 28(25-26):2982-990.

Division 2: 325-175 cal BP

Tree rings from Tasmanian Huon pine (Lagarostrobos franklinii) chronology.

Hua Q, Barbetti M, Zoppi U, Fink D, Watanasak M, Jacobsen G. 2004. Radiocarbon in tropical tree rings during the Little Ice Age. Nuclear Instruments and Methods in Physics Research B 223-224:489-94.

Hogg A, Hua Q, Blackwell P, Niu M, Buck C, Guilderson T, Heaton T, Palmer J, Reimer P, Reimer R, Turney C, Zimmerman S. 2013. SHCal13 Southern Hemisphere calibration, 0-50,000 years cal BP. Radiocarbon 55(4), this issue.

\section{Center for Accelerator Mass Spectrometry (lab code: CAMS)}

Data set number: 6

Tree rings from Tasmanian Huon pine (Lagarostrobos franklinii) chronology.

Zimmerman S, Guilderson T, Buckley B, Cook E. 2010. Extension of the Southern Hemisphere atmospheric radiocarbon curve, 2120-850 years BP: results from Tasmanian Huon pine. Radiocarbon 52(2-3):887-94.

Hogg A, Hua Q, Blackwell P, Niu M, Buck C, Guilderson T, Heaton T, Palmer J, Reimer P, Reimer R, Turney C, Zimmerman S. 2013. SHCal13 Southern Hemisphere calibration, 0-50,000 years cal BP. Radiocarbon 55(4), this issue. 